\title{
Writing, Legal Rule and Abstract Coin - the Archaic Beginnings of Scientific and Philosophical Thought
}

\begin{abstract}
Important for the scientific and philosophical mode of thought is the issue of circumstances that lead to the emergence of such type of reflection, different from traditional ways of explaining the reality by mythological beliefs. The spiritual search of a philosophising man turned out to be a reflection upon rule, upon the all-governing principle, i.e. both the natural world (cosmos) and the relations between people. This mode of thought evolved when a need and possibility for writing down (setting out) abstract legal norms (nomos) for the sake of certainty and verifiability of judgments arose. It was vital also for the trade and in particular for ownership (civil law), whose value was abstractly expressed in monetary money. These were the crucial factors in the initiation and development of scientific and philosophical (abstract) thought. Other fundamental conditions for the development of science and philosophy included liberty, equality and respect for otherness, as well as the non-orthodox character of beliefs (myths). These were ensured by the civic, cosmopolitan and economically developed polis, particularly the democratic one. Such conditions for the development of science and philosophy have proved to be universal and timeless.
\end{abstract}

Keywords: philosophy, ancient Greece, ancient Greek law, polis, science, abstract norm, monetary money, symbolic value, written language, lawgiver, nomos, physis.

Prof. Jerzy Oniszczuk - Chief of the Department of Public Administration, Warsaw School of Economics; e-mail: jerzy.oniszczuk@sgh.waw.pl; ORCID: 0000-0003-4526-7334. 


\section{Introduction. Reasons for the Emergence of Philosophical Mode of Thought}

It is an important issue of the scientific and philosophical mode of thought to determine what circumstances have lead to the emergence of such an unusual type of reflection, so different from traditional ways of explaining the reality by way of beliefs. Something must have happened that gave rise to a new quality in reasoning, which in turn enabled the borders of the traditional, mythological account of the world and man's place in it to be crossed. The first people to look at the reality clearly, as opposed to viewing it through myths that provided certain truths on the world and rules used to organize the universe, were the so-called archaic Greek philosophers of nature. Making use of observation, yet still drawing on mythology, they put forward a rational reflection, thus overcoming the somewhat naive mythological explanations.

The results of those evolving philosophical conceptions increasingly opposed the earlier poetical stories - myths, in which the world was shaped by deities. The archaic thinkers' approach was different not only to some 'simple' modes of explanation, religious narratives, but - which is particularly important - also from the manner of thinking employed by earlier developed civilisations of the East or Egypt. And it is this very fact of existence of cultures that were more ancient that the Greek one that has given rise to the question of why it was not in them that science and philosophy were created. The question of fundamental significance for the evolution of the philosophical mode of thought is thus about the reasons for the emergence of philosophical mode of thought - i.e. one that is characterised by independent speculative rationalisation - in archaic Greece.

Many factors behind the rise to the rational explanation of the world have been named. Some of the most commonly cited include: Greek travel and trade in the region of the Mediterranean Sea, the nature of the Greek religion (polytheism), the rise of the social structures of polis and the development of the written form of language ${ }^{2}$ as well as the Greek expansion by way of setting up colonies in the East and West. These conditions were to significantly conduce to the development of an

2 G. Stamatellos, Introduction to Presocratics, Malden, Ma.-Oxford 2012., p. 4; W. Lengauer, Religijność starożytnych Greków, Warszawa 1994, pp. 11-43. 
independent, rationalising mode of thought. And it is this mode of thought - referred to as logocentric - that is commonly indentified as characteristic of the Greek culture.

It is in that Greek culture that the idea of logos and a reasonable, coherent reflection and belief in the value of independent thought is supposed to have come to being. In the light of the above, the question is how it occurred that such a logocentric culture was developed in Greece. ${ }^{3}$ It is in the area of the Greek culture that the vision of principle (arche) was put forward, which is particularly different from both the Persian religious culture and the 'Egyptian hermetism'. The Ionian city of Miletus (a Greek colony of c. $10^{\text {th }}$ century BC) was first to demonstrate this otherness of Greeks, an otherness differentiating them particularly from Persians. This was followed by the activity of the Pythagoreans ${ }^{4}$ in the area of the so-called Magna Graecia, which was to influence the development of sciences and a knowledge markedly different from the achievements of Egyptian priests. ${ }^{5}$ It can be mentioned that it is in Miletus that rational explanations of the universe first appeared, and where a mechanism of continuous reason-based criticism of earlier conceptions by subsequent ones was formed. Particularly, openness to various ideas is identified as underlying this practice. The Greeks borrowed a lot from more developed cultures, except for the system of beliefs, although some great systems, e.g. those adopted in Egypt and Mesopotamia, defined even the origins of the world as well as the divine pantheon. An awareness of diversity arose in that respect, and people began to reflect upon the multitude of beliefs, upon the meaning of religions - one's own or those of others, arriving at a moment where an analysis of religions was initiated in the light of their powers of persuasion as to the vision of cosmos and their ability to explain the reality. Such considerations led to an insufficient level of satisfaction with the traditional explanations, and to expectations of accounts that would be able to describe the universe better. And those expectations, i.e. a certain social demand (of rather few) for such, were addressed by individual explanatory visions of several Milesians. They did that because, as mentioned before, there had appeared a certain space for considerations and freedom to present more courageous, persuasion-oriented views of the world. Those explanations were to gain credibility thanks to a revolutionary novelty, i.e. rationality. The truth of an account was, therefore, influenced by the satisfaction of the criterion of rationality.

The emergence of a new, rationalising and using observation-based arguments mode of thought, defined as philosophy, proved possible due to the appearance of

3 G. Szulczewski, Aporie filozofii a kondycja racjonalizmu, Warszawa 2006, p. 40.

4 J. Oniszczuk, Użyteczność wiedzy, władzy, państwa and prawa w poszukiwaniach pitagorejskich, "Państwo Prawne" 2015, 1(5), pp. 7-57.

5 G. Szulczewski, op. cit., p. 60. 
specific cultural, economic, social, political and legal conditions in ancient Greece. What is especially important is that a number of liberties are necessary for philosophical thinking to arise (particularly freedom of speech and tolerance of such freedom), and these first appeared in Greek poleis. This state does not seem to have been experienced by other communities that had earlier created different cultures. Moreover, it has been argued that a sufficient level of such liberties first occurred in Greek colonies rather than in mainland Greece. Hence, the beginnings of philosophical investigations take place just in the oldest colonies in the East (Miletus), and then in the West (Magna Graecia). It is in Ionia that the first attempt was made to explain the natural reality and all beings in a rational way for the sake of knowledge itself. Ionian - and then Italian - philosophers attempt, adopting a cosmological perspective, to explain the entirety of existing entities by reducing them conceptually to a 'principle' or several principles. The subsequent continuation and unusual development of philosophy in Athens, but not, for instance, in Sparta, was also related to an exceptional level of freedom that the citizens of Athens enjoyed. ${ }^{6}$ One might even say that these conditions sort of 'awaited' people who would make use of such 'liberties' in order to ask questions about the view of reality and undertake speculation in that respect. The above remark ought to be supplemented by the important circumstance of the metropolis' customs being weakened as a result of being transferred to colonies. It is in the colonies that law started to be written down. This was, among other things, because of the fact that new conditions bred difficulties with following customary rules, particularly where e.g. a colony remained under the influence of more than one metropolis. All in all, the world of colonies was dominated by a different, less 'burdened' and more vivifying spirit compared to that prevailing in the distant metropolises with their conservative customary laws and rituals. And perhaps the courage to take risks and the approval of the same was greater in that world than in the metropolis itself.

In most general terms, Greeks travelling to other, distant worlds and staying in the colonies of Asia Minor, Italy or Sicily, had to exercise a much greater flexibility in accommodating to new conditions in order to survive or succeed. Their own social and religious norms did not bear the mark of orthodoxy which would make other rules and truths impossible to adopt. However, they retained at the same time a certain core of a flexible community narrative which accompanied them incorporated in poetical texts. Greeks also carried with them a certain legal tradition of the community and its organisation. Under such circumstances, the question of 'why' could be hardly answered simply with an explanation like: 'for it has always been so', referring to a specific order of a specific deity or consisting in an absolute,

6 G. Reale, Historia filozofii starożytnej, Vol. 1, Lublin 2008, pp. 20, 52. 
excluding any discussion, answer of the 'wisest' ruler. Thus, seeking answers in a pluralist colony environment required persuasive arguments since there could have been many free and equal 'formal' authorities, each offering their own account. Explanations and guidance in a world of diverse mythologies, deities and their commandments were losing their causal power. Naturally, dialogue and understanding required a reciprocal recognition of the partnership of another person as well as seeking a rational argument. Pre-philosophical thinking appeared following the pluralism of mythical truths, and was hence present in questioning the explanatory certainty of myths as well as in the criticism of poetical and mythological authorities, particularly that of Homer.

\section{The alphabet and the development of the written form of language. Teaching}

An important factor in the development of a culture, and hence of codified law and of the presentation of pre-archaic poetry, law or philosophical thought, was the written (alphabetic) form of language. The emergence of writing $\left(8^{\text {th }} \mathrm{c} . \mathrm{BC}\right)$ is deemed as the key moment for the development of the so-called archaic era in literature, although in the area of philosophy, the epoch begins with the first philosopher-scientist, and lasts until the appearance of the first conception characteristic of the so-called classical era, i.e. that which equipped rationality with a moral key (Socrates). It should be added here that the language in question was not the first one to be found on the territory of Greece; for it was a language described in a legend, then in circulation, according to which Linos of Thebes, a mythical poet and musician, converted the Phoenician alphabet into Greek. ${ }^{7}$

The earlier, the oldest Greek language emerged in the $2^{\text {nd }}$ millennium BC. It evolved out of the language of an Indo-European tribe which arrived on the territory of Greece in the $3^{\text {rd }}$ millennium BC (c. 2100 BC). Many words of the conquered non-Indo-European people can be found in Greek. The oldest Greek-language testimonies come from the early $14^{\text {th }} \mathrm{c}$. BC. These are texts in syllabic script - the so-called Linear B as opposed to the older Linear A writing, so-called Cretan, which preceded pictorial script (of c. $2000 \mathrm{BC}$ ). Following many centuries of break in the use of script and with it being somewhat forgotten during the Dark Ages, written accounts only reappear in $8^{\text {th }} \mathrm{c}$. BC. Texts are written using an alphabetic script acquired from Phoenicians. And the earlier script - Linear B - appeared after the older, Cretan, system (A) was adopted by Mycenaean invaders of the island (15 c. BC).

7 I. Krońska, in: Diogenes Laertios, Żywoty i poglądy stynnych filozofów, Warszawa 2006, p. 6, footnote 2. 
This was supposedly when script A evolved (i.e. it was adapted to express the Mycenaean language), although it is not certain whether Linear B evolved in Crete or already in the Peloponnese. The extant Linear B tablets of $14-13$ c BC (e.g. Knossos, Pylos, Thebes) display a single form of the Greek language, i.e. the so-called Achaean dialect. Following the collapse of the Mycenaean culture, the dialect was supposedly diversified. ${ }^{8}$ Anyhow, the areas dominated by the Mycenaean culture used the Greek language. ${ }^{9}$

The written form of Greek (the language itself, as has been mentioned, evolved in the second millennium BC), which emerged after the Dark Ages, was of Phoenician (Semitic) origin. The earlier phase of the development of the Phoenician script is usually associated with Syria and Palestine (the Western-Semitic region). Phoenicians simplified the earlier script, syllabic in nature, and their alphabet consisted of 22 characters. ${ }^{10}$ The term 'alphabet' comes from the Phoenician language as it consists of the first two characters of the script, namely 'aleph' and 'bet'. The alphabet adopted by Greeks differs but slightly from that adopted by Phoenicians in terms of the shape and order of letters. However, the Semitic system was not a fully phonetic script as it lacked separate characters for vowels, which means that the reader would interpret which of the possible sounds fitted the context. Therefore, the Greek innovation consisted in introducing separate vowel characters (a, e, i, o, $\mathrm{u}$ ) and symbols for those consonants which were missing from the Semitic language (i.e. ph, kh). It resulted in the script -characterised basically as a simplified syllabic script - being converted into an alphabetic script. For it is in that system that separation was first made between all essential sounds of speech, i.e. vowels and consonants, and that such sounds were assigned relevant symbols (letters). This operation resulted in such a great flexibility of the system that it is still being employed by

8 B. Bravo, E. Wipszycka, Historia starożytnych Greków, Vol. 1, Do końca wojen perskich, Warszawa 1988, pp. 19-20, 74-75, 77. A linguistic uniformity has been observed of the texts from $2^{\text {nd }}$ half the $2^{\text {nd }}$ millennium, referred to as the Achaean dialect (after the term Achaeans used by Homer). A comparison of tablets from $14-13 \mathrm{cc}$. BC and those from the $1^{\text {st }}$ millennium $\mathrm{BC}$ leads to a conclusion that the older is similar especially to the Arcadian, Cypriot and, slightly less, Aeolian dialects. After $12^{\text {th }} \mathrm{c}$. the Achaean dialects, under the influence of Dorian dialects, gave rise to other dialects from which in turn Attic and Ionian dialects evolved (in $1^{\text {st }}$ millennium). With the migration of people from $11^{\text {th }}$ to $9^{\text {th }} \mathrm{cc}$., the Ionian and Dorian dialects migrated also to the coast of Asia Minor. As A. Krawczuk reminds us (Mity, mędrcy, polityka, Warszawa 1975, pp. 63 and 67), a kind of palace archive was found in the ruins of Knossos in 1900, surviving in the form of clay tablets containing Linear B script. A similar archive was discovered in Pylos in 1939 (it is from that city that Homeric Nestor came). In Mycenae, only a several dozen tablets were found. Linear B was also found on amphorae discovered in Thebes, Mycenae, and Tiryns.

9 J. Chadwick, Odczytanie pisma linearnego B, Warszawa 1964.

10 Other alphabets, e.g. the Akkadian syllabic alphabet contained 285 characters, Mycenaean Linear B comprised over 80 characters, whereas the Greek syllabi alphabet from Cyprus - 56. 
a majority of modern languages. It also often stressed as important that the Greek system applies to languages which are characterised "by 'pronunciation' in the usual sense of the term". This innovative adaptation of the Phoenician system is believed to have occurred in a Greek-Phoenician society, existing in a place from which script could easily and quickly reach the entire Greece (non-class commonality of the written language). Al Mina, a Greek trading post ${ }^{11}$ (on the coast, near the river Orontes mouth in Syria) from which the script might have reached, through the islands, mainland Greece and beyond, is often named an example of such language-forming centre (this view lacks, however, sufficient evidence). The implications of such linguistic modifications proved truly revolutionary, and not only on account of the rapid propagation of the alphabet itself, also outside Greece, i.e. in Italy, where, both directly and through the Etruscan culture, it reached Rome to "spread along with its heritage across entire Europe in modern times". ${ }^{12}$ For, in essence, the Greek alphabet and syntax created a mechanism that was conducive to the precision and communication in abstract thought and by means of categories. ${ }^{13}$ It might be added here that at the beginning of the abovementioned evolution of the written language, two main varieties of that language existed, viz.: Eastern (Ionia, islands of the Aegean Sea, Corinth, Megara, and Argos) and Western (the remaining part of the Greek region). The shift of Athens from the Western to the Eastern group occurred as part of the so-called Eucleides' reform in late $5^{\text {th }} \mathrm{c}$. BC, which, on account of Athens' importance, led to the Eastern variety being adopted in the Greek world. The Western variant, on the other hand, lies at the foundations of the Latin language. ${ }^{14}$

The oldest traces of existence of the borrowed Greek alphabet date back, as we have mentioned, to c. $750 \mathrm{BC},{ }^{15}$ but Greeks soon appreciated the great utility of script, which by c. $650 \mathrm{BC}$ had become quite commonly known in Greece. It may be noted here that there are certain unsubstantiated views which date the beginnings of the Greek alphabet to c. 850 BC, or even earlier. For the Phoenician alphabet was supposedly first encountered by the Greeks of Euboea ( $\left.9^{\text {th }} \mathrm{c} . \mathrm{BC}\right)$, and they - the

11 A trade post (emporion) was a settlement set up by groups of Greek traders coming from various places. Such settlements were created on the outskirts of developed states, e.g. Egypt.

O. Murray, Narodziny Grecji, Warszawa 2004, pp. 127-131.

13 G. Stamatellos, op. cit., p. 4.

B. Bravo, E. Wipszycka, op. cit., p. 117.

The oldest writing artefacts are considered to be a chip off a vessel from c.a. 750 and the so-called 'Nestor's cup' from c.a. 750-725. The latter comes from Pithecusae Island (currently Ischia near Naples). The cup features a poetical text written in hexameter: "Whoever drinks from this cup, him straightaway the desire of beautiful-crowned Aphrodite will seize." On the grounds of this and other texts (e.g. one on the vase found in Athens dated 730-720), it has been argued that the character of the inscriptions as well as the idea and manner of inscription thereof support a view that alphabet had been in use earlier. (See B. Bravo, E. Wipszycka, op. cit., p. 115). 
founders of Pithecusae - were to introduce the script to the West. There are also views expressing a possibility of existence of earlier varieties of Greek alphabets because the characters of some of those were supposedly similar to the Phoenician characters that had come out of use in $11^{\text {th }} \mathrm{c} .{ }^{16}$ When it comes to first literary works appearing in the written form, these were most probably Homer's poems, and with an even greater likelihood, these could have been the works of Hesiod and Archilochus. Anyway, it is the times of Hesiod that are perceived as a moment of an "unquestionable rise in importance of written poetry". The following texts will appear in writing: a list of Olympic winners (776 BC), the date of establishment of a colony in Sicily (734 BC), a list of Athenian officials (683 BC), Zaleucus's laws in the Italian colony of Epizephyrian Locri (c. 650 BC), and Draco's laws of Athens (c. 625 BC). Due to the necessity of frequent presentation and verification of legal content, it is precisely law that proved to be the kind of complex public documentation that needed to be recorded. On the other hand, the typical form of everyday communication and information exchange between Greeks was conversation. It is thought that the Greek society became 'fully literate' at the beginning of $4{ }^{\text {th }} \mathrm{c} . \mathrm{BC} \cdot{ }^{17}$ However, the awareness of the practical importance of writing is evidenced by e.g. an agreement concluded late $6^{\text {th }} \mathrm{c}$. in the hamlet of Datalla, with a professional scribe who was supposed to record and keep the recorded information in the form of official documents. ${ }^{18}$

It should also be added that from the emergence of writing in $8 \mathrm{c}$. BC until nearly the end of 4 th c. BC, the local dialects of the various cities were used to produce non-literary texts. Literary works, on the other hand, beginning with Homer's works and those attributed to Hesiod, were created in poetical language, which was not in use in everyday life. For that language was a result of many centuries of the tradition of oral accounts of the epic works. Actually, older Ionian dialects lay at the root of that language. As evidence of the poetical significance of the language, the poetry of Hesiod is often quoted, who lived in Boeotia and used an Aeolian dialect, and also that of his father speaking the same dialect used in Kyma (Asia Minor), where he lived. Now, Hesiod's language is not a Boeotian language, but a Homeric one. Later authors of epic poems used the language of the prototype of the literary genre until the end of Antiquity. The language of Homer's poems influenced the languages of various literary genres (elegy, lyric, drama). Literary works appeared in the all-Greek poetic language making references to certain dialects and thus is

\footnotetext{
16 W. Lengauer, Starożytna Grecja okresu archaicznego and klasycznego, Warszawa 1999, p. 21.

17 O. Murray, op. cit., pp. 130-131, 137.

18 W. Lengauer, Starożytna Grecja..., p. 21.
} 
described as tinged with the flavour of such dialects. The language of poetry was, however, never a pure dialect of a single given city. ${ }^{19}$

Given that the first prose works were written in the Ionian dialect $\left(6^{\text {th }} \mathrm{c} . \mathrm{BC}\right)$, prose authors continued to write in this dialect for some time regardless of where they lived. In $5^{\text {th }} \mathrm{c}$. BC this approach changed. For instance, Thucydides began creating in the Attican dialect in late $5^{\text {th }} \mathrm{c}$. One of the reasons behind this was probably the development of works by Athenian orators who, although not focusing on literary work, did write in Attican for practical reasons. However, considering the content of their works and the social impact of rhetoric as well as the development of rhetoric schools and those teaching literary, dramatic,, and philosophical writing (from Plato on), and finally the novelty content of documents produced by Athenian democratic institutions, it turned out that those various forms of expression in the Attican dialect began to gain in importance. It was precisely in this dialect that the Greek intellectual life developed. And to such a degree that the Attican dialect, featuring some Ionian elements, started becoming an all-Greek language from mid $-4^{\text {th }} \mathrm{c}$. BC onwards; it first spread among the intellectual elite and then became a language of administration and the everyday life of Greeks of the time. ${ }^{20}$

The findings of Harold Innis and Marshall McLuhan treating interpersonal communication as a fundamental social force and changes in the manner in which communication takes place as 'catalysts stimulating both social and private relations' have formed the grounds for an anthropological study by Jack Goody and Ian Watt on the Greek civilisation, covering inter alia the significance of the emergence of script. ${ }^{21}$ The researchers set out to demonstrate that writing underlay the majority of changes taking place in archaic Greece. It provided the reasons for 'a pursuit of democracy, development of logic, rationalism, scepticism, rise of individualism and personal alienation and replacement of primitive, mythological accounts of the past with critical historiography'. Not only did writing enable rules, which were previously diversified and volatile, to be consolidated, but it also made it possible to make the content of the more standardized, clearly defined rules available to a large number of people. With the spread of writing, legal principles become solidified and judges' arbitrariness restricted, since writing contains a sort of a mechanism conducive to limiting ambiguity and volatility of interpretation that are considered characteristic of oral tradition. The disclosure of discrepancies between the content embodied in written form and the functioning of a certain

19 B. Bravo, E. Wipszycka, op. cit., pp. 21-22, 118 and the work quoted therein: J. Chadwick, The Prehistory of the Greek Language.

20 B. Bravo, E. Wipszycka, op. cit., pp. 22-23.

21 See: O. Murray, op. cit., pp. 135. 
reality is said to have led to the emergence of criticism. At its foundation was a thought on rationality that rules the public and private spheres alike. Writing proved not only to have an initiating nature, but also to contribute to fundamental changes in Greece. It was conducive to the increasing role of poetry and the development of the epic tradition. In the case of Ionian philosophy, the recorded statements were to enable precision of subsequent critical considerations, whereas in historiography, a critical evaluation of old accounts led to mythography converting into history. Moreover, the undertaking to have law codified in writing favoured its reliability and durability as well as overcoming the prevalence of the aristocratic system in favour of democratic systems which evolved in 5 c. BC. In any case, writing was of great importance to many changes, although - as Murray notices - this is not to mean that 'the ability to write was an element so essential that it could be deemed as a sufficient cause (...) of those changes'. ${ }^{22}$

The importance of the implications of the appearance of script is sometimes judged using the criterion of the purpose that literacy served (Goody). Unlike typical cases where writing serves the functions related to the existing forms of social life', and in particular remains in 'a special relation to the spheres of religion and politics', i.e. essentially serves to petrify and reinforce the existing system, 'Greek writing evolved in a lay atmosphere and initially served mainly lay goals'. Therefore, due to inter alia a lack of a priestly cast (protecting religious dogmas) and a substantially open character of the political system, the conditions emerged for writing to support the abovementioned lay tendencies. This is how the important influence of writing on poetry, law or maintenance of memory is explained. ${ }^{23}$ Perhaps this was the reason conducive to the emergence of medical or mathematical treatises or texts on geography and astronomy, and eventually Herodotus' works on 'the history of fathers' (Histories).

Despite the considerable diversity and multitude of Greek dialects, different findings, views or rules became commonly accessible thanks to a common and uniform Greek language used in both the public and private spheres. The archaic political and social structures developed from $6^{\text {th }} \mathrm{c}$. BC onwards had exerted impact on the development of early philosophy, its questions and the mechanism of dialogue. The overall changes taking place in the Greek world of the time, accompanied by political movements and the emergence of the democracy of the poleis, contributed to the diversity of practices and customs, enabled critical reflection, independent argument, and decision-making. The education developing in such conditions favoured deliberative attitudes. The foundations for literary education were laid

\footnotetext{
22 O. Murray, op. cit., pp. 135-137.

$23 \quad$ Ibidem, p. 137.
} 
by the accounts of the archaic era poets (Homer and Hesiod) and also Orpheus (a more legendary figure). This poetry was employed as an authoritative voice to express human heroism, divine ways, and the structure of the natural world. Greek education and culture encouraged thus asking questions and dialogue. In such an environment, archaic philosophers evaluated, criticised, and developed traditional beliefs and a reflection upon the nature of the cosmos and man's life. The spirit of competition (characteristic of aristocratic culture), promoted by Greeks - particularly by means of sport competitions - was also of importance to the development of philosophical investigations. Such events included also musical and poetic performances. The best contestants distinguished themselves not only in terms of fitness, but also mental skill. The spirit of mental competition can be found in contentious argumentation. A possibility of engaging in a critical dialogue is deemed as an important mechanism leading to philosophical reflection. Archaic thinkers remained in a critical and creative philosophical dialogue with their teachers and followers. For instance, Anaximander challenged the cosmological views of Thales, yet he himself was criticised by his student, Anaximenes. Heraclites did not attach much importance to the popular teachings of Pythagoras and Xenophanes, whereas, following in his footsteps, Parmenides advocated a vision of becoming that was quite different to that of Heraclites, and supported the material monism of Ionian thinkers. Zeno's paradoxes of motion and infinite division of matter were approached differently by Empedocles and Democritus. Finally, the concept of Anaxagoras's nous was criticised by Socrates as inadequate. Yet another element shaping the philosophical thought was the manner of expressing oneself. Prose became a new means of expression for the majority of thinkers of the time. Pherecydes of Syros is named as the first to have created a prose text in a philosophical context, which was probably contemporary to the Fables of Aesop (620-560 BC). In 6 c. BC, Anaximander and Anaximenes wrote their works (On Nature) in prose, choosing it as a form more suitable to the subject than the elegant poetic style of Homer or Hesiod. Some thinkers, e.g. Xenophanes, Parmenides, and Empedocles, rejected the new tool, however, and used the measure and style of the earlier formal poetry, adapting it to their own mode of thought. ${ }^{24}$ The shift towards prose appears as a result of the Ionian 'enlightenment', as a means that satisfies the requirements of philosophical-scientific precise and critical analyses better than poetry.

As regards the important issue of education, public schools do not appear until the Hellenistic era. Earlier, there were private schools for children, while more advanced education for adults was associated with sports centres - gymnasia. In the pre-Hellenic period they were found outside the walls of poleis. And later, gymnasia

24 G. Stamatellos, op. cit., pp. 4-6. 
became the centres of the main public institution, i.e. ephebeia - a centre for civic and military education of the youth. ${ }^{25}$ Writing opened the doors to the development of a range of areas; it enabled the emergence of the sui generis court judgments in the form of texts that people could have recourse to in order to establish a situation or the content of public laws in effect. However, it was not until the ability to write and read had become common that the certain authority of writers - scribes was diminished. It was not revolutionary for the development of philosophy and science themselves; however, as for the dissemination of their results and their impact on reality - its importance was immense.

It may be pointed out, incidentally, that literature has recognised the usefulness of the Greek language to the beginning of philosophising. It is presumably, on account of its nature, fit for speculative enquiries. The Greek language's feature of the neutral gender (neutrum), allowing for a presentation of 'what is an intentional object of thought (...) as a subject' certainly contributes to that end. A pre-cognition of concept was found in such a neutrum denoting something ubiquitous, since it supposedly contained what 'is common to all things', i.e. a feature which 'appears in every entity'. There is also another feature identified in Greek, which is the occurrence of the 'copula' (-), the use of the word 'be' to combine the subject with the object, which creates a sentence structure', and in Hans Gadamer's opinion, 'this fact is the deciding factor'. ${ }^{26}$ However, this opinion is not further justified.

Regardless of the features of specific languages, it may be claimed that script allowed for texts to be created. They made it possible, on the one hand, to present one's (author's) view, and, on the other hand, for a text to be read (by its recipient). The two 'agents' were no longer required to be in the same place at the same time to engage in a continued conversation. Such conversation could be of abstract nature. Written text enabled an advanced reflection to be presented abstractly and be read with consideration and interpretation.

\section{The lawgiver. Codification of Customary Law. Constitutions}

Law in Greek communities emerging from the Dark Ages evolved before the arrival of script ( $8^{\text {th }} \mathrm{c}$. BC). It was in the hands of rulers (symbolised by Homer's Agamemnon), and later by aristocracy who both made the law and sat as judges. Basileus (a judge-king) handed down judgments (themistes), which reflected a rather lax ap-

25 M.H. Hansen, Polis. Wprowadzenie do dziejów greckiego miasta-państwa w starożytności, Warszawa 2011, pp. 162-163.

26 H.G. Gadamer, Początek filozofii, Warszawa 2008, p. 22 and B. Snell and K. Reinhard quoted therein. 
proach to the law. But e.g. in Hesiod's account, such judgments should be made in accordance with justice (dike). The question was then what the source of such justice was and which judgments were compliant with it. Thus, in this case, an idea of writing down the laws (customs) aimed at combining judging with justice. ${ }^{27}$ The law which was recorded gained special authority.

It is commonly emphasised that in the archaic era there appeared - together with the civilisation of military hoplites - an express demand for certainty of law and rulings of aristocratic judges, and for fairness of such law. Writing down the applicable law was to serve that purpose, although it was not the only reason for law to be recorded in writing. In either case, written law clearly expressed the specificity of the citizenship of poleis. It made the system more rigid and enabled the differences in laws and political systems of the various poleis to be perceived more easily. It was in Sparta's laws that ascetic solutions for democracy were introduced. Spartan law and institutions served to form the qualities making up the hoplite ethos (particularly the virtues of courage and discipline) and the content of a polis of 'similar' people. Other solutions for a liberal democracy, different from those adopted under the model polis of hoplites in Sparta, were offered in the law in Athens. A feature of the Athenian democracy was a more flexible approach to social issues, with a particular focus on social justice. However, the normative appearance and continuous surfacing of differences between the two approaches to democracy led to a tension between the two centres and, as a result, to a specific reflection upon democracy, where the philosophical dimension of democracy was to demonstrate itself. In other words, it is especially the variety of normative solutions that inspired the philosophical reflection upon the social order and man in a state. Yet, there is another conflict arising in the above, simplified, characteristic - one between a pro-state model with a publicized citizen (its extreme form being a totalitarian state), and a democratic approach with an independent individual's rights at its root. History shows that the latter system is preferred not only by those of a more creative attitude.

It has been mentioned that the problem of respecting justice, of crucial importance to the issue of laws being written down in the ancient era, is that arising in connection with the injustice of the ruling aristocracy. The social memory, particularly poems, contained a thought that the earlier traditional customary rules had been under the auspices of a king who received their power to pass judgements from Zeus himself. Thus, the power to make judgments had a religious background and justification. Such just king was supposed to ensure a fruitful continuity of nature.

27 Homer, Odyseja (Księga XIX, w. 109-114) in: B. Bravo, E. Wipszycka, Historia..., p. 196. See also in: Homer, Odyseja, trans. L. Siemieński, ed. Z. Kubiak, Warszawa 1990, p. 291. 
The fragment of Odyssey quoted to characterise a 'blameless king' states that the king, 'with the fear of the gods in his heart, is lord over many mighty men, upholding justice; and the black earth bears wheat and barley, and the trees are laden with fruit, the flocks bring forth young unceasingly, and the sea yields fish, all from his good leading ${ }^{\prime 28}$ Thus, a just king guaranteed a harmony among the natural forces, whereas an unjust one, by disturbing such harmony, brought calamities. An inclination to continue the administration of justice, as implanted by deity, was displayed by the aristocracy ruling following the decline of monarchy. However, their 'postroyal' administration of justice must have led to many objections since e.g. Hesiod (Works and Days) criticised the judgments of the aristocratic judges, pointing out their injustice from Zeus's expectations point of view. As time went by, the religious grounds for judicial power were losing importance. At the same time, an increasing social awareness of unfair judgments serving the interests of aristocracy led in the Greece of the time, as mentioned above, to the demand that the customary laws be written down. It was expected that comparing judgments with written law would make it possible to exercise supervision over the judiciary. ${ }^{29}$

During the aristocratic rule, critics deemed the Greek law and courts as not legitimised by divine action nor by any divine sets of commands (commandments). The divine contribution of Zeus only consisted in delivering the right to judge and oversee judgments. This observation is supported by referring to procedures of judgments made by elders as described by Homer and Hesiod, and to a social view that such rulings ought to fall within certain borders. The law so understood functioned to prevent excessive freedom of judges or their arbitrariness. Hesiod promoted a more general view, disagreeing with instances of unjust judgments. His position is expressed in the observation that judges can be deceitful and a statement that judges' verdicts upset Dike. ${ }^{30} \mathrm{~A}$ codification of law in written form enable, thus, above all, a clear exposure and consolidation of customary rules, but it also contributed to stabilisation of judicial interpretation, often perceived as 'crooked' and arbitrary.

A number of the abovementioned needs led to the emergence of the so-called lawgiver (nomothetes), and such a lawgiver proved to be of great importance in the legal culture of Greece. The impact and work of a lawgiver can be viewed from the viewpoint of distinction between the rules established by himself, a person of

28 Homer, Odyseja, Book 19, lines 109-114.

29 B. Bravo, E. Wipszycka, op. cit., p. 196.

30 O. Murray, op. cit., pp. 86-87, 95. 'Often times the entire town suffers due to a single perpetrator,/ Who not knowing righteousness repeats crime after crime repeats', Hesiod, Prace $i$ dnie, Wrocław 1952, pp. 15-16; J. Oniszczuk, Hezjod: prefilozofia pracy, sprawiedliwości and hybris, [in:] M. Latos-Miłkowska, Ł. Pisarczyk (eds.), Prawo pracy między gospodarką a ochrona pracy. Księga jubileuszowa Profesora Ludwika Florka, Warszawa 2016. 
semi-divine wisdom, and statutes adopted by the polis's Ecclesia. Whereas the latter, simply speaking, were easily modified, a lawgiver's act acted as a kind of a constitution of permanent or considerable durability (e.g. the laws of Lycurgus in Sparta). Therefore, the law established by a lawgiver could only be changed by another lawgiver of proper authority. Solon, as a lawgiver, was to leave Athens for ten years so as not to be forced by a tyrant to amend the law. ${ }^{31}$

The most general meaning of the institution of a lawgiver is often found in the tendency to limit the influence of aristocracy and maintain the achievements of customary law. The question is the goal, the manner in which the lawgiver is appointed, and their competence. As regards the goal of a lawgiver's appointment, it was to codify the law and contain it in written form. Thus, it was not about a lawgiver 'thinking up' the law, but rather about essentially recording the existing customs. Lawgivers would be elected from among those versed in law, and vested with power and considerable liberty in the treatment of the pre-existing legal tradition, as well as granted an enormous independence from the views of the people. This sui generis 'absolute' power led a lawgiver to recognise his own power. The lawgiver did not justify his actions by invoking divine influence, but rather appealed essentially to " his own sense of justice and faith which the entire community place in them'. The authority usually attributed to him made polis' institutions credible, and he was often treated with respect due to half-heroes or perceived as a 'divine' founder of the colony. Besides, the special situation of colonies favoured the appearance of the first lawgivers. ${ }^{32}$ Colonies placed a bigger emphasis on law to be written down on account of, among others, the fact that there were difficulties in new conditions with following the customary rules, particularly where e.g. a colony was under the influence of more than one metropolis. But when settling in new territories, Greeks also encountered other cultures whose elements may have in turn impacted the colonisers themselves. There was therefore a need for a common body of laws. The earliest lawgivers in colonies include: Zaleucus from an Italian colony of Epizephyrian Locri (c. $650 \mathrm{BC}$ ) and Charondas of Catana in Sicily (late $7^{\text {th }}$ c. or early $6^{\text {th }}$ c. BC). ${ }^{33}$ The lawgivers of Greece proper included in particular Philolaos of Corinth, active in Thebes (early 6th c. BC), the legendary Lycurgus of Sparta (7th c. BC), and Draco of Athens (between 621-620 BC), and, somewhat later, Solon. The principal lawgiver of Crete was supposedly Epimenides in late $7^{\text {th }} \mathrm{c}$. BC. Among the earliest

31 Herodot, Dzieje, Warszawa 2004, p. 28.

32 O. Murray, op. cit., pp. 241-243.

33 He gave laws not only to Catana, but also to many other Sicilian poleis, e.g. Leontinoi, Naxos, Himera. His laws were also to be used in Southern Italy, on certain islands of the Aegean Sea and in Asia Minor (Capadotia). 
lawgivers Aristotle mentions an otherwise unknown Pheidon of Corinth, who was supposedly active as early as $8^{\text {th }} \mathrm{c}$. BC, and also cites the legendary figure of Onomacritus (Locrian) of Crete. ${ }^{34}$ Among such lawgivers there were sages such as Solon, but also tyrants such as Draco and Periander of Corinth (625-585). It may be mentioned here that the people's acceptance for a tyrant stemmed often from the latter's law-giving activities as by introducing written laws, such a tyrant was actually challenging the aristocratic, liberal attitude to customary justice. Also, the people accepted tyrants supporting laws which were democratising the social relations; an example of such a tyrant was Peisistratus, under whose rule Athens applied Solon's law. Such 'democratic' tyrants might have been supported by a civic army of hoplites seeking recognition of their services to the polis, on a par with aristocracy.

Somewhat elaborating on the above remark, it could be added that the first of the abovementioned lawgivers - Zaleucus - was to come up with standards in the area of private property protection, and in politics and morals as well. He is also believed to have demanded his officials to be objective and protect the internal order. Charondas, on the other hand, is attributed with introduction of a court procedure and court liability for perjury. Philolas set down the rules of inheritance in order to maintain a certain number of plots of land (kleroi). The mythical Lycurgus was to put forward a regulation concerning the political regime of the polis, and was also said to be the author of the body of fundamental laws applied in Sparta - the Great Rhetra (which has, however, been questioned by researchers). It has been recognised that the laws of Dreros (Crete) concerning actions of public authorities might have come from late $7^{\text {th }}$ c. BC. ${ }^{35}$ In Athens, Draco's role involved writing down the customs in all 'areas' of law, whereas that of Solon's - introducing a certain form of legal democracy and social justice. As regards Draco, Aristotle deemed worth mentioning only the severity of punishment, while speaking highly of Solon's law-making as limiting the influence of oligarchy, terminating the slavery of people, and restoring ancient democracy. Pittacus of Mytilene (Lesbos) was also supposedly appointed c. $600 \mathrm{BC}$ to set down the applicable laws. Aristotle finds his regulation whereby 'the drunken, should they beat someone, shall suffer a greater penalty than the sober; for people commit more violent acts when drunk than when sober, so they did not consider the lenient opinion whereby the drunk should rather be forsaken, but gave regard to the social benefit' ${ }^{\prime 36}$ quite characteristic.

The above mentioned process of codification of customary law, its conversion into written law of a polis, lasted a considerably long time. This new law was per-

\footnotetext{
34 Arystoteles, Polityka, Warszawa 2004, p. 55 (1265 b), footnote 26, p. 74 (1274 a).

35 W. Lengauer, Starożytna Grecja..., pp. 56-57; Arystoteles, op. cit., p. 75 (1274 b).

36 Arystoteles, op. cit., p. 73 (1274 a), p. 75 (1274 b).
} 
ceived as the foundation of the human society (Hesiod, Archiloch, Solon), as a factor removing the interpretation leeway, and the society treated it as a kind of a ruler (nomos basileus). The law, which regulated a vast range of interpersonal relations, including family and religious matters, subordinated those relations to civic duties, hence attaching significance to justice (dikaiosyne). A transcendent dimension of written law appeared as a result of a common recognition that it corresponded to natural law, and eventually that it was compiled by a lawgiver - a special person with extraordinary mental powers. However, political disputes and fights within the states and between them resulted in the law being violated. Hence the problem of inviolability of law by humans proved to have a philosophical meaning. For proving the necessity of obedience of a state law, which was expected to be compliant with natural (divine) law, drew the attention to the issue of the meaning (essence) of law. However, due to the weakening of the religion of the Olympic gods in the early $6^{\text {th }}$ c., and also due to the imperfect vision of the homogenous nature of the universe, which treated man as an element of nature (the Milesians), a new proposal of philosophical rationality emerged based on Orphism. These new pursuits attempt for the first time not only to put forward a rule governing the cosmos (arche), but also to address the issue of man as a particle in the universe, the relationship between the cosmos and the individual (Pythagoreanism). ${ }^{37}$

The pre-philosophical thought emphasised the necessity to live in a certain tribal community or, later, a political one within a polis (Homer), being a structure superior to an individual. This dimension of polis was to be defined by its nature and laws. The earliest philosophical pursuits, following earlier visions, tried to rationalise the norms governing the entire reality (cosmos), so they formulated laws governing nature, but also the community, and determined the position of an individual with respect to nature and the social reality. These laws of nature also required man to abide by them. The earliest philosophical pursuits did not distinguish between e.g. divine laws, natural laws, and those laid down by the polis. Those reflections contain reminiscences of the era of family-tribal communities, which was to justify the universalism of the earliest philosophical visions of a polis. The pre-philosophical visions of the world were then adopted by the first natural-law conceptions, which meant that a polis (a political community) proved to be a product of nature, an element of the cosmos (a part of a whole). This was the Pythagorean conception. But the natural character of a polis was also supported by other approaches, e.g. those of Xenophanes and Heraclitus. These approaches pointed to the obviously natural dimension of the state and subordination of the interests of an individual to the good of the community. The necessity to live in a polis, for which the cosmos

37 J. Gajda, Prawo natury and umowa społeczna w filozofii przedsokratejskiej, Wrocław 1986, pp. 30-31. 
is a model, involves the philosophical thought adopting a position with regard to the existing, concrete social and political world, the state, law, and the situation of man. This approach means that archaic philosophy did not base its rationalisations exclusively on pre-philosophical accounts. In any case, philosophical investigations designed various rational accounts of the position of man in a polis, his subordination to the state and law. This also entailed a specific approach to valour (arete), i.e. citizens were expected to be active. The rationalisation of this approach with regard to political life is where the foundations of political thought are found. ${ }^{38}$

The conception of nature and its law became also interested, as mentioned above, in the sphere of social life and of the polis. In this respect, philosophical visions rationalised above all the idea of polis and its laws (nomoi). It was pointed out that the recording of customary laws in written form (a long-lasting process of codification) led to the creation of state laws (nomos) whose role was to provide the foundations for the conduct of the human community and the functioning of a polis, to define a polis as an entity to which people were to assign their own meaning. In the awareness of the citizens of a polis, the feature of nomos was both the divine content (themis) derived from Zeus and the content derived from dike (possibility to exercise one's rights). Laws provide the foundation to a polis, as they shape its structure and functioning. It was possible to have such laws written down, as mentioned above, only by a lawgiver, i.e. a person who has obtained wisdom - learned the law of nature and set down in accordance therewith (nomos), enabling the proper functioning of their polis. ${ }^{39}$

The expectation that the laws of a polis be in agreement with the laws of nature was expressed in those archaic philosophical conceptions which undertook to rationalise the state and law. The question of such agreement was raised by those criticising the existing nomoi, e.g. the Pythagoreans, Xenophanes or, especially, Heraclitus. ${ }^{40}$

Perhaps the codes created by the first lawgivers included customs of particular communities, regulations that had been inspired by norms set out in the written laws of other poleis, and eventually various innovations proposed in order to solve certain social problems of the time. But the fact that recognised wise men and philosophers made references to lawgivers means that the views of those persons were

38 Ibidem, pp. 163-165 and W. Kornatowski quoted therein, Uniwersalizm and indywidualizm poznawczy w greckiej teorii państwa and idem: Przesłanki nauki o państwie w klasycznej Grecji; Pojęcie państwa $w$ świetle badan teoretycznych.

39 J. Gajda, op. cit., pp. 165-166.

40 Ibidem, pp. 166, 54; J. Oniszczuk, Sprawiedliwość jako wieczna and regularna wymiana wedtug inteligentnej miary. Poszukiwanie prawa, [in:] J. Osiński (ed.), Kapitalizm a sprawiedliwość społeczna, Warszawa 2016, pp. 13-67. 
not indifferent to the society. And perhaps the interpretations and social conceptions of philosophical nature were also reflected in written legal texts. In other words, codes contain information on the views of the thinkers - lawgivers.

It may be recalled that in the earlier Homeric era there was no developed system of law or courts, but rather a certain set of taboos and customs and public arbitration. As for a legal arbitration court procedure, it is presented in the form of public deliberations resembling the proceedings of an assembly. In this case, members of the council of elders act both as mediators and on their own behalf. It is not possible to impose a resolution on the parties since the resolution is reached by both parties accepting the settlement. With time, such arbitration was replaced by a court with a code, protected by public sanctions. ${ }^{41}$ And in the later, codified, law, as mentioned above, an attempt was made to reach a certain universalisation of solutions. For instance, the laws of Solon were said to aim at sorting out the experience of 'generations of professional peacemakers'. Those laws introduced order into the world of custom interpretation made by elder aristocracy. However, the authority of elders was limited by the progress in the implementation of equality of citizens before law, ${ }^{42}$ thus the new written law was conducive to the democratisation of the poleis' system. The demand for written law meant that, as a rule, regulations were expected to be impartial and impersonal, and to treat citizens equally. Such impartial law, applied in equal measure to all entities, was the basis of the image of justice in a polis. Judgments were to be fairer, compared particularly to those made by aristocratic judges who had applied customary rules known to them only (and interpreted arbitrarily). The laws written down by lawgivers can be said, on account of the special character and content thereof and of the nature of its authors, to have been the first constitutions.

Quite importantly, with the arrival of an impersonal and universal legal system employing a means of influence in the form of rulings, a common regulator of social relations appeared. The legal sense was expressed in nomos (agreement, convention) against the idea of physis. This mode of thought was inter alia to awake a more general reflection of a scientific-philosophical character. An abstract legal formula appeared as an inspiration for philosophical thought. It could happen especially at that time, when, as a result of legal recognition, the monetary ore money emerged, i.e. money that featured impressed symbols denoting certain conventional (legal) values.

\footnotetext{
41 O. Murray, op. cit., pp. 84-85.

42 The Solon's statement is given as an example: "I recorded the laws for the good and the bad/ All people alike to the simple Dike/ I subordinated.
} 


\section{The significance of coins and norms}

It has not been unambiguously established, as of yet, when the first coins were made and what was the immediate reason behind that. It may be reminded that the appearance of a minted coin in trade was preceded by exchange, which involved inter alia precious metals e.g. in the form of lumps, bars or iron rods. This system was slowly replacing simple barter. When an emblem was impressed onto such lump, this marked the appearance of coin money, for this mark was associated with the guarantee of the value of the coin related to the place of origin. The first coin turned out to be a piece of metal 'acknowledge by custom' (nomisma). Those barrels, devised in 7th c. BC in Lydia, treated in the literary tradition of the Ancients as coins, were made of electrum as early as in Midas period from c. 700 BC, whereas king Gyges (c. 687-652 BC) supposedly normalised the issuance of barrels in line with their colouring, and specified their values. After $650 \mathrm{BC}$, barrels were superseded by minted coins. Later, another Lydian king - Croesus (561-546 BC) introduced coins made of pure gold or silver. ${ }^{43}$ The fact that Greek poleis in Asia Minor were developing in the neighbourhood of the Phrygian and Lydian monarchies was probably not insignificant to the appearance of coins in Ionia after $650 \mathrm{BC}$. Lydia's influences extended over various Greek poleis, including such important ones as Ephesus, and, to a certain degree, also Miletus. ${ }^{44}$ And it is in Ephesus of late $7^{\text {th }} \mathrm{c}$. BC that the first own minted electrum coin was to appear. As regards the first silver coins on the territory of Greece proper (and perhaps in the entire Hellas), they are said to have been minted in Aegina (c. 595 or c. 580 BC). An own coin in Athens appeared presumably c. $575 \mathrm{BC} .{ }^{45}$ According to the numismatic view, the minting of coins in Aegina took place in c. $570 \mathrm{BC}$, and accordingly later in Corinth and Athens. However, the discovery of smooth barrels, 'impressed', ridged, and minted electrum coins ${ }^{46}$

43 N.G.L. Hammond, Dzieje Grecji, Warszawa 1994, pp. 174 et seq.

44 Phrygia emerged in the era of the People's of the Sea, in $2^{\text {nd }}$ half of $8^{\text {th }}$ c., ruled by the legendary king Midas. The Lydian state subordinated gained control over Greek cities in late $7^{\text {th }}$ and $6^{\text {th }}$ (kings Alyatter, 617-560 and Midias). However, Lydia eventually became largely Hellenised, and Lydian rulers did not interfere with the business of the cities subordinated to them. In $7^{\text {th }} \mathrm{c}$., the relationships with Greece proper begin to intensify again. (B. Bravo, E. Wipszycka, op. cit., p. 263).

45 O. Murray, op. cit., pp. 312-313. According to Murray, the abovementioned dating of Lydian electrum coins is sometimes questioned and it has been argued that they may have been minted later, i.e. in the period between 625-600 BC, or under the rule of king Alyattes II (c.a. 617-560) or even c.a. 590 (the numismatic view).

46 Electrum is an alloy containing gold, silver, and small amounts of copper. It was first found in Sardis (Lydia). It can be also mentioned here that an alternative numismatic chronology dates the minting of the first Lydian coins to c. 590, which would mean that coins appeared in Aegina only slightly before 570 and later than in Corinth. As regards Athenian coins - tetradrachms, they appeared c. 510 (mines of Laurion). The appearance of a certain standard is linked with the tetrad- 
in the foundation of the Artemis temple in Ephesus (a foundation deposit of the first temple-from c. 545 and possibly complemented with the construction of the second temple) has caused divergent opinions to appear in relation to the earliest issues, which are dated to between 680 and $600 \mathrm{BC}$. They even do not exclude the possibility of Greek precedence in creation of this money. Most commonly, however, it is assumed that coins, as understood today, were minted in Lydia and also in the abovementioned Artemisium in Ephesus after 650 BC. According to this interpretation, following Ionia, coins were to appear in Aegina (c. $625 \mathrm{BC}$ ), in Corinth (c. 610 BC), and in Athens (c. 600 BC). Aegina's money was the coin in circulation in Peloponnesus for over two centuries (as the Aegina's monetary system was adopted by many Greek poleis). ${ }^{47}$ On the other hand, Persian money production began in late $6^{\text {th }} \mathrm{c}$. BC. The coin was then adopted, with considerable delay at times, by other Mediterranean peoples, e.g. Phoenicians, Carthaginians or Etruscans. Coins became common in the Mediterranean basin in late $6^{\text {th }} \mathrm{c}$. BC. The coin became a characteristic feature of the Greek civilisation. Greeks were first to appreciate and use the discovery of monetary money. Coins were minted in nearly every city and became a manifestation of independence (the political meaning of coins). Seeing that, however, every coin made of precious ore was of considerable value, it could not be used in retail trade. Therefore, precious coins were not so commonly used in everyday trade, but rather as a form of precious ore gathering. Quite importantly, the reason for states minting coins was rather their financial obligations (e.g. payment for work, army supplies, etc.) and payments to the state (taxes, customs, fines). It was after some time that coins found broader application also in trade. Either way, a lack of a token coin (C.M. Kraay) is deemed a substantial argument against the initial presence of the coin in retail trade. ${ }^{48}$ The monetary ore money first acquired greater importance in wholesale (long-distance maritime) trade. In retail trade, on

rachm, which dominated the Aegean area, especially after 233. Earlier, such standardisation (the earliest one) of the silver coin was supposed to ensure success to the coin minted in Aegina. A series of coins of various weight, minted in Aegina, is said to have had an impact on the development of trade-based economy. Such coins were treated as an international exchange means until the last quarter of $5^{\text {th }}$ c. See M. Cross, The Creativity of Crete. City States and the Foundations of the Modern World, Oxford 2011, p. 138.

47 N.G.L. Hammond, op. cit., pp. 174-175, 766 and a statement by Aristotle on the beginnings of the monetary system of Lydia and Aegina quoted therein: 'For the sake of exchange, people agreed among themselves that they would give and take materials useful per se and easy to apply in everyday life, such as iron, silver, and other metals; initially they were only determined by size and weight, but later they began to be stamped in order to avoid having to measure as the stamp showed the amount of metal used from then on'.

48 B. Bravo, E. Wipszycka, op. cit., pp. 208-209 and e.g. the paper quoted therein: C.M. Kraay, Archaic and Classical Greek Coins. 
the other hand, such money became common after the appearance of the token coin made of bronze at the turn of $6^{\text {th }}$ and $5^{\text {th }}$ centuries BC.

The invention in the archaic era of a means of exchange, i.e. coins made of precious ore, gained a considerable importance, as mentioned above, for trade relations, and contributed to their intensification and growing extent. This innovation had impact not only on the trade and economic life, but also on a change in the mindsets of Greeks. Standardised electrum barrels and such later coins led to a change in the attitude to ownership and to ownership's coverage in law, in poleis' policies, and in culture. The Lydian invention - a measure in the form of monetary money (electrum) resulted in the development of monetary economy becoming a feature of the archaic era. Coins began changing the perception of value of various objects. They replaced other manners of value measurement. One could express the entirety of one's possessions, one's estate in monetary terms. The measurement of value by directly comparing two products was substituted with a universal intermediate (contractual) measure allowing for determination of the value of every single thing. The assessment of value by means of the intermediate factor, money, reflected a new mindset of the assessor, i.e. one that was detached from comparing individual items. Abstract thought was exercised this way. However, we can mention here also a rather isolated view which questioned monetary money as a factor having commonly revolutionary implications for value, trade, and wealth. ${ }^{49}$

Accepting the revolutionary role of coin, it can be claimed that the transport infrastructure (marine highways of sorts) immensely facilitating commercial, cultural exchange and travelling were all supported by the infrastructure of sorts provided by monetary money, backed by the development of abstract thought and trust in symbolic marks on metal coins expressing value.

The development of abstract and common monetary metal money was accompanied by the emergence of financial (material) value, also expressed symbolically. A golden coin proved to be not only a specific, alienable object but at the same time an abstract criterion of measurement - a standard allowing for determination of the value of exchangeable objects. Thus, coin came to act as an equivalent of a certain good, but also a common regulator (similar to law). Its symbolic dimension concerns the conventional form of money in economy. The meaning of the coin has even been interpreted, similarly to law, as an expression of the victory of nomos (agreement,

49 Sometimes (e.g. Hans van Wees) a view is supported that the coin provided merely a more convenient means of exchange. The passive approach of the state to money is thus interpreted as its interest in supplies rather than in private trade. Therefore, substantial trade and supporting commerce means that the state saw a certain benefit in that respect and understood the importance of its own activities with respect to money. See M. Cross, op. cit., p. 170 and H. van Wees quoted therein (The Economy). 
convention) over the idea of physis (matter). It was possible for the monetary system to come into the social life in the archaic world of poleis due to the achieved social and economic levels, especially the level of trade (maritime exchange). The developing monetary system was accompanied by an increasing understanding of the notion of common equivalence. The monetary system thus came detached from persons and suggested the coin as a universal means of exchange. The impersonality and universality, characteristic of the monetary system, is also a feature of legal systems. And it is the emergence of a system of written law that facilitated the development of a complex monetary system. The feature proved also, as mentioned before, important to the scientific and philosophical thought. The Heraclitan conception, its description of the logos and fire is often offered as an example of inspiration with the features of monetary and legal systems. And although the philosophy does not expressly use the notions of nomos and physis, it is assumed that it addresses the opposition between those categories. ${ }^{50}$ The monetary system in question enabled the formation and development of a notion of a universal, global equivalent. Coins expressed a shift from direct barter to a contractual one by means of a recognised value of coins. Coins mark the transition from private valuation to a more general value system. The idea of a universal equivalent (equal value) or measurement standard contains a certain way leading to the philosophical conceptions of value exchange in a cosmic economy. ${ }^{51}$

It could be said then that the scientific-philosophical mode of thought, i.e. abstract in nature, emerged in the place where inter alia an abstract and general system of civil law and a system expressing conventional value by means of the coin evolved. The highest level of economic development was achieved by the poleis of Asia Minor, particularly Miletus, where the first known philosophers appeared.

The development of a monetary money system, particularly of token coins, brought about changes in the social and political situation of the Greek poleis. Its feature is the departure from the dominance of archaic aristocratic ideology. According to that concept, owning precious metals meant having basic and unchangeable values. This was to prove the 'natural' superiority of aristocracy. Whereas coins offer a mechanism of questioning the primacy of such natural superiority as the means of payment, i.e. money (nomisma), acting in accordance with the social convention (it accepted variability). According to Kurke's account, the monetary money overcame aristocracy's monopoly on precious goods which circulated in the form of gifts (physis) in a closed circle of that social stratum, thus ensuring its hierarchical

\footnotetext{
50 A.W. Nightingale, The Philosophers in Archaic Greek Culture, [in:] H.A. Shapiro, Introduction, [in:] idem (ed.), The Cambridge Companion to Archaic Greece, Cambridge 2007, pp. 187-188.

51 Ibidem, p. 172.
} 
status. Coins, on the other hand, introduced precious metals to common trade under the symbolic power of the polis. In other words, such marked coins of the polis offer an opposition to the so-called natural authority of aristocracy. Despite, therefore, the fact that coins were related to a precious metal, they were already a token of, as mentioned above, the victory of the concept of nomos over physis. ${ }^{52}$ In terms of wealth, coins proposed 'democratisation' in place of the 'natural' supreme role of aristocracy by introducing levelling.

\section{Conclusion}

It has turned out that the meaning of the spiritual search for a reflexive, philosophically-minded man lies in a rule. A principle that governs both the physical, natural world (cosmos) and relations between people. An abstract, written legal norm (nomos), created for the purpose of trade and ownership (civil law) as abstractly expressed in money was not without its contribution to the initiation and development of the scientific and philosophical thought. And it should be added only for the sake of formality that other conditions fundamental to the development of science and philosophy were liberty, equality, and respect for otherness, as well as the non-orthodox character of beliefs (myths). And these were ensured in a civic, cosmopolitan, and economically developed polis, particularly a democratic one. Such conditions for the development of science and philosophy have proven to be universal and timeless.

52 Ibidem, p. 188 and L. Kurke quoted therein (Coins, Bodies, Games, and Gold). 